Алексеј Тимофејев

Филозофски факултет, Универзитет у Београду

Институт за новију историју Србије, Београд

al.timofev@gmail.com

https://doi.org/10.18485/ai_godine_ww1.2019.ch6

94(497.11:470)"1914/1918"

355.48(497.11:470)"1914/1918"

\title{
БАЛКАН И РУСКО-СРПСКИ ОДНОСИ У ПРВОМ СВЕТСКОМ РАТУ 1914-1917.
}

Anстракт: На основу релевантне литературе, објављених мемоара и архивске грађе аутор сагледава руску политику према Балкану уочи и за време Првог светског рата и долази до закључка о кључној улози фебруарске револуције 1917. у променама спољне политике Русије, а услед тога и о драстичној прерасподели послератног уређења Западног Балкана - од планова уједињења српских земаља дошло је до реализације концепта заједничке државе СХС.

Кључне речи: Русија, Србија, Први светски рат, руска револуција 1917, стварање Југославије, руско-српски односи

Истакнути српски историчар Б.Храбак је сматрао да је „сломом царске Русије нестало [...] православног ослонца српске владе, а на Миљуковљева ${ }^{1}$ уста почела се и у Русији јављати југословенска мисао (...) У целини узев, избијањем Фебруарске револуције југословенска идеја, као прогресивна, је добила, а великосрпска је из-

1 Први министар спољних послова Привремене владе формиране након фебруарске револуције који је био на свом положају 2. (15.) марта - 5. (18.) маја 1917 года. 
губила“.2 У не толико кристалисаном облику али веома слично ово мишљење су делили и поједини други југословенски историчари пре њега. ${ }^{3} \mathrm{C}$ обзиром на то да након пада монопартијских држава и дефинитивног урушавања Југославије појам „прогресивног југословенства“ више нема толико апсолутну вредносну моћ, потребно је детаљније сагледати тачку бифуркације коју је назрео истакнути југословенски историчар. Процена значаја ове тачке бифуркације, круцијалности и предодређености (или релативне спонтаности) промена мора сигурно утицати и на глобално сагледавање свих догађаја 1917. у српској и руској прошлости. Пре свега морамо потражити одговор на питање коју је будућност царска Русија назирала за Србију пре револуционарног слома 1917.4

Прве идеје о будућим територијалним променама граница српске краљевине настале су у вези са британским предлогом о пацификацији Бугарске уз повратак

2 Богумил Храбак, „Србија и фебруарска револуција 1917. године“, Зборник радова Филозофског факултета XIII, (Приштина, Филозофски факултет, 1978), 51, 57.

3 Херман Вендел, Борба Југословена за Слободу и Јединство, (Београд: Народна просвета, 1925); Milada Paulova, Jugoslavenski odbor: povijest jugoslavenske emigracije za svjetskog rata od 19141918, (Zagreb: Prosvjetna nakladna zadruga, 1925); Ante Mandić, Fragmenti za historiju ujedinjenja, povodom četrdesetgodišnjice osnivanja Jugoslavenskog odbora, (Zagreb: Jugoslavenska akademija znanosti i umjetnosti, 1956); Ante Smith Pavelić i Ivan Meštrović, Dr. Ante Trumbić: problemi hrvatsko-srpskih odnosa, (München: Knjižnica Hrvatske revije, 1959); Milan Marjanović, Londonski ugovor iz godine 1915. Prilog povijesti borbe za Jadran: 1914-1917, (Zagreb: Jugoslavenska akademija znanosti i umjetnosti, 1960).

4 И то не само назирала, већ је и активно помагала Србију у остваривању нове будућности од самог почетка Првог светског рата. Видети: Алексеј Тимофејев и Дарко Кремић, Руска војна помоћ Србији за време Првог светског рата, (Београд: Институт за новију историју Србије, 2014). 
делова Македоније који су ушли у састав Србије након Другог балканског рата. Постоји руски документ којим се одговарало на британски предлог. То је меморандум који је 7. (20) јануара 1915. године руски министар спољних послова, Сергеј Сазонов, уручио британском и француском посланику у Петрограду. У њему се говорило да се руски министар иностраних послова боји да Грејова понуда о прерасподели територија неће задовољити никога. И заиста, показало се да је било управо онако како је руски посланик у Србији, кнез Трубецки, 8. (21) јануара 1915. године јавио руској царској влади: „српска влада изразила је неспремност да учини сасвим одређене уступке у замену за магловита обећања“.

Много интересантнији докуменат јесте дипломатска депеша бр. 9, послата 26. (13) јануара 1915. руском министру инострнаих послова, Сергеју Сазонову. Аутор тог важног телеграма је тадашњи руски посланик у Краљевини Србији, кнез Григориј Трубецки. Сврха депеше била је да се руски министар упозна са српским погледима на територијална питања. Телеграм представља послаников коментар предлога које је раније изнео министар иностраних послова Велике Британије, Едвард Греј, у вези са могућностима територијалног проширења Србије и, с друге стране, од ње очекиваних територијалних уступака. То је требало да буде заједнички предлог сила Антанте - Велике Британије, Русије и Француске. Посланик Трубецки је настојао да

5 Тај меморандум се цитира у телеграму који је министар иностраних дела С.Д.Сазонов послао руским представницима у Лондону (А. К. Бенкендорфу), Паризу (А. П. Извољском) и Београду (Г. Н. Трубецком). Международные отночения в эпоху империализма: документы из архивов иарского и Временного правительств 1878-1917 г2. , Серия 3: 1914-1917, Т. 7, ч. 1, (Москва-Ленинград: Соцэкгиз, 1935), 66-67. 
дефинише како српска страна гледа на британска очекивања и територијалну комбинаторику на Балкану, па је ступио у контакт са угледним српским научницима Јованом Цвијићем и Стојаном Новаковићем, који је био и вођа Напредне странке.

Можда најважније опажање кнеза Трубецког, које је изнео у својој депеши, јесте: „Питање о томе у каквом односу ће бити Србија са земљама које ће успети да припоји сада је врло нејасно и самим Србима. До тога је дошло највише зато што је рат изненадио Сpбију, а ратна дејства су практично раздвојила Србе из Краљевине и Србе из Аустроугарске, те им је сада немогуће да успоставе било какав контакт“. дене реченице практично су сажете главне политичке и друштвене околности у којима је требало дати одговор на питање: Србија или Југославија? Краљевина Србија уочи избијања Првог светског рата није очекивала скори распад Аустроугарске, нити се надала да јој може силом отети територије насељене српским и другим јужнословенским живљем. Односи са моћним суседом на северу били су лоши још од Мајског преврата 1903. И посебно након успеха у Балканским ратовима, али рат ипак није сматран потпуно извесним. ${ }^{7}$ Аустроугарска објава рата у лето 1914. године је последње што јој је било потребно после крварења у два Балканска рата. Зато су у српској интелектуалној и политичкој елити идеје о томе како би требало да изгледа држава (или државе) ослобођених Јужних Словена биле још магловитије од поменутог предлога министра Греја. Тек током рата, када се потреба за дефинисањем ратног циља показала акутном, почела је потрага за прецизнијим одговором. Поред наведених

6 Международные отномения в эпоху империализма, 112.

7 Ђорђе Станковић, Никола Пашић, савезници и стваране Југославије, (Зајечар: Задужбина Никола Пашић, 1995), 36, 43, 46. 
околности, давање јасног одговора на државно питање ометала је и друга чињеница, коју је опазио кнез Трубецки: рат је Србијанце одвојио и супротствио Србима с оне стране Дрине и Саве (као и осталим Јужним Словенима). Одавно је у српској историографији примећено да је то био део стратегије Беча. Пославши на фронт против Србије трупе у којима је био врло висок проценат Јужних Словена и Чеха, Аустрогарска је желела да постигне одређени политички ефекат: у случају њене победе, могло се тврдити да су цару верни Словени победили Србију, док би пораз код хабзбуршких Словена развио мржњу према победничкој Србији. ${ }^{8}$

Трубецки је, анализирајући насталу ситуацију, закључио да се не може предвидети да ли ће исход рата довести до припајања јужнословенских крајева аустроугарске Србије или ће се на том простору створити неколико малих самосталних држава. Он је чак сматрао да су најзрелији политичари тога били свесни, а да је председник српске владе, Никола Пашић, већ тада био спреман на врло широке уступке Хрватима да би задобио њихове симпатије према Србији. У начелу, у Београду се почетком 1915. године сматрало, према Трубецком, да области насељене православним становништвом треба припојити Србији у истом статусу као и њене постојеће тероторије, док са Хрватском односе треба уредити на други начин, кроз неке форме аутономије. Свест о дубини верских и културних разлика између римокатолика и православних још није била укорењена у српском друштву пре Првог светског рата, чији интелектуалци су се саосећали са етнофилетистичком паролом Друштва Св. Саве «Брат је мио које

8 Андреј Митровић, Србија у Првом светском рату, (Београд: Српска књижевна задруга, 1984), 106-107. 
вјере био». У овом амбијенту могли су деловати далековидо и упозоравајуће речи кнеза Трубецког с краја његове депеше: „Не може се рећи у шта ће се преобразити садашња Србија, уколико се више него удвостручи по броју становника. Нове придошлице са собом ће донети и нове навике и схватања".

Опрез и недоумица услед двосмислености онога што је уједињење јужних крајева Аустроугарске са Сpбијом могло да донесе, могу се видети и на Цвијићевој скици, коју је Трубецки додао свом извештају. Осим предратних граница Србије и Црне Горе, на њој су назначене северне и западне границе словенског етноса, као и груба линија поделе на претежно римокатолички и претежно православни простор унутар будуће државе или држава. Примећују се и две посебно шрафиране области, према Италији и Румунији, означене (већ тада, 1915. године!) као територије од којих се током усаглашавања може одустати. Свакако је постојала одређена хијерархија приоритета и рачунало се са неопходношћу усклађивања са претензијама околних држава. Иако је Цвијићева скица обухватала чак Целовец, Печуј, Бају, Темишвар и Карашов, вероватно се није сматрало да сви ти градови могу по етничком или неком другом принципу припасти Србији или Југославији. Слична карта служила је касније као пропагандно средство српске делегације на конференцији мира у Паризу 1919-1920. године. Уосталом, иако је Цвијић своју карту са „строго провереним научним подацима“ посланику Трубецком дао „у поверењу“ и ограђујући се од политичке стране питања, не треба сумњати да је то, у ствари, било дискретно испитивање дипломатских кругова - на шта Србија, у перспективи, може рачуна-

9 Международные отночения в эпоху империализма, 114. 
ти. Уосталом, Трубецког није заварао инсистирањем на својој „научности“, јер је руски посланик у пропратној депеши професора Ј.Цвијића назвао иронично „званичним кројачем српске владе“. ${ }^{10}$ Мислило се, наравно, на „кројача“ државних граница. Одраз овог неповерења према перспективама српско-хрватског суживота постао је руски пристанак на Лондонски уговор из априла 1915.

Након евакуације Србије 1915., драматичних неуспеха Италије на фронту и рапидног слабљења Аустроугарске, руске дипломате су морале детаљније да сагледају будућност јужнословенских народа у Аустроугарској. Година 1916. представљала је специфичан и без патетике трагичан период српске историје. Италија је у то време покушавала да добије пристанак од Русије на очување послератне независности Црне Горе, што је сигурно изазивало забринутост Пашића, настројеног ка ликвидацији неприродног стања - две државе једног народа по завршетку Светског рата. ${ }^{11}$ У склопу већ разрађене пропагандне праксе у Русију је отишла и научна мисија А. Белића и С. Станојевића. ${ }^{12}$

Начелник департмента у МИД-у царске Русије, државни саветник А. М. Петрјајев, који је радио у руској дипломатији све до 17. новембра 1917, пружио је веома разрађену слику аналитичких претпоставки будућности Србије везане за послератну судбину Аустроугарске. Петрјајев је пред саму револуцију сматрао „да би стварање јединствене велике Србије или Српско-Хрватске државе било најбоље решење југосло-

\section{0 Исто, 112.}

11 Юрий А. Писарев, Сербия на Голгофе и политика великих держав 1916 г., (Москва: Наука, 1993), 144.

12 Љубинка Трговчевић, Научниии Србије и ствараюе југословенске државе: 1914-1920, (Београд: Народна књига, 1986). 
венског питања и у руском интересу је било тежити томе да се та политичка комбинација оствари. Снажно словенско царство са 14 милиона становника утемељено на обалама Јадрана, чији интереси се нигде не косе са руским, било би веома пожељан елеменат наше будуће западноевропске политике“. ${ }^{13}$ Међутим, Петрјајев је приметио очигледне проблеме на путу остваривања овог плана - „супротстављање Енглеске и Француске великосрпским плановима и идејама стварања на Јадрану велике српске државе која би гравитирала Русији“. С друге стране, на путу стварања заједничке државе Јужних Словена Петрјајев је видео проблеме у случају насилног припајања територија Хрвата, који нису могли да буду безболно асимилирани од стране Срба услед мањка становништва, снага и различитости вере и културе. У будућности југословенске државе руски дипломата је назирао и потенцијални конфликт са Италијом, која ће се борити не само за Трст и Истру, већ и за већи део Далмације. У том контексту, оцењујући реални однос снага, сматрао је да би постизање споразума о подели јадранске обале са Италијом било од користи за Србију, јер би ослабило конфликт између њих и спречило могућност италијанског мешања у српско-хрватске размирице. Услед тога сматрао је да очување редуциране Хабсбуршке царевине уз издвајање источнословенских и српских али не и пољских, хрватских и чехословачких територија не може да буде искључено из низа пожељних по Русију варианата послератног расплета. Ипак овај расплет није био префериран у његовој аналитичкој процени. ${ }^{14}$

13 Архив внешней политики Российской империи (АВПРИ), ф. Политархив, д. 5270, л. 17.

14 Као и друге претпоставке, ова се обистинила, јер је у периоду између светских ратова, бесна због губитака у хрватској Далмацији, Италија почела да подржава сепаратистичке тензије код 
Погледи о потреби да Беч сачува утицај на део католичког словенства су у још већој мери налазили подршку код конзервативних лидера царске Русије Б. В. Штирмера и А. Д. Протопопова у последњим месецима владавине династије Романов. Руски реакционарни кругови су тумачили Југословенски комитет и круг око Томаша Масарика ${ }^{15}$ као нуспојаву коју су, према начелнику српског корпуса, генералу Михаилу Живковићу, називали „западни утицај“ ${ }^{16}$

Без обзира на наведене варијанте расплета Великог рата (које је преферирао конзервативни део руске јавности) прихватљиве за уске српске националне интеpece, штетне по словенску и пре свега хрватску будућност и услед тога погубне за јужнословенски програм, Петрјајев се (као и већи део руских царских стручњака за Балкан далеких од конзервативности) придржавао идеје о потребама стварања јужнословенске државне заједнице уз споразум не само са Хрватима, већ и са Словенцима. Већ 1915. руски дипломатски кругови су потврдили српском посланику у Петрограду М.Спалајковићу да у српске планове послератног уједињења морају ући и Хрвати и Словенци. ${ }^{17}$ Пред саму фебруарску револуцију 1917. Петрјајев је мислио да ће Ср-

хрватског, црногорског и албанског становништва Југославије. С друге стране, без обзира на затегнуте односе са Београдом, у току постојања Југославије, однос Италијана према Србима пре 1914, 1941-1945. и после 1991. био је бољи него код већине других народа који су живели у суседству Србије.

15 Чешко виђење супротности између Ј. Дириха (1847-1927) и Т. Масарика (1850-1937) видети у: Евгений Ф. Фирсов, Т. Г. Масарик в России и борьба за независимость чехов и словаков, (Москва: Индрик, 2003).

16 Ову слику је веома пластично, мада и са позиција традиционалне мржње према Хрватима-франковцима, описао М. Живковић. Војни архив (ВА), п. 16, к. 44, ф. 1, д. 12, 203-205.

17 Архив Југославије (АЈ), Ф. 80, ф. 2, 466-468. 
бија по завршетку рата морати да задовољи Хрвате аутономијом и сабором, али не на уштрб државног јединства. Петрјајев је предлагао да територије са словеначким становништвом такође уђу у састав проширене државе, уз намиривање евентуалних италијанских и аустријских (превасходно) захтева. У исто време црногорско питање се посматрало као део српског питања (у склопу одлуке о потреби послератног уједињења две државе српског народа). Руска дипломатија саопштила је дефинитивно и српским и црногорским представницима већ у јуну 1915: „колико ће Русија у будуће водити рачуна о краљу црногорском зависиће од тога, да ли Србија то жели“ ${ }^{18}$

Са приступом руских царских дипломата јужнословенском уједињењу као начину решавања проблема ослобођења свих делова српског народа слагала се и српска влада. Реакција на изнети став А. М. Петрјајева била је Пашићева белешка од 24. фербуара 1915: „Границе обележене и то су крајње за попуштање, у право минимум, а разуме се да ћемо тражити целу Словеначку. Што се тиче месне аутономије ми ћемо је примити, ако на томе буду настојавали, али без жртве за целину Српске државе“. 19

Интересантно је, али у даљим преговорима руска страна је сугерисала да српски програм не би смео „да представља освајачку политику на словенском југу“, већ да има „тежњу за остварењем заједничких идеала и интереса који би Србију стављао у дужност не допустити да један део Хрватске и Словеначке остане под туђином“. ${ }^{20}$ И руска научна јавност делила је погледе МИД-а царске Русије на јужнословенско уједињење,

\footnotetext{
18 AJ, Ф. 80, ф. 2, 710.

19 AJ, Ф. 80, ф. 2, 469.

20 AJ, Ф. 80, ф. 2, 472.
} 
пре свега као на начин решавања српског националног питања, у оквиру чврсте и јединствене државе са доминацијом Срба, али и одређеном аутономијом Хрвата и Словенаца. Погледе које је на јужнословенско питање имао Александар Михаилович Петрјајев (1875-1933), искусни дипломата, са врхунском спремом (познавао je 14 језика и имао универзитетске дипломе Петербуршког универзитета, Правног факултета и Факултета источних студија), делио је и, водећи у то време, руски стручњак за историју Јужних и Западних Словена - Николај Владимирович Јастребов (1869-1923). Професор Петербуршког универзитета, Јастребов, написао је и објавио обимну монографску студију са варљивим називом Велика Србија. ${ }^{21}$ У ствари, у овом раду говорио је о немогућности самосталног опстанка уске српске државе која ће стално бити играчка у рукама средњоевропских сила, већ о потребама уједињења свих Срба, Хрвата и Словенаца у једну заједничку државу која ће бити базирана на узајамном поштовању мањих народа и доминацији већег - српског народа, који би требало да даิ Словенцима и Хрватима у оквиру будуће културну аутономију и локалну самоуправу. Закључио је: „не само остварење идеала Велике Србије већ и даљи опстанак савремене мале Србије обезбедиће се углавном уз моћ и помоћ Русије“.22

Као што смо већ рекли у руском спољнополитичком телу постојала је одређена препрека на путу остваривања наведених планова. Радило се о значајној подељености руске јавности (па и руске политичке елите) на

21 Николай В. Ястребов, „Великая Сербия, как разрешение южно-славянского вопроса в великой войне 1914-15 гг.“, Вопросы Мировой войны: сборник статей, ред. М. И. Туган-Барановский, (Петроград: Правда, 1915).

22 Исто, 172. 
неколико „спољнополитичких“ оријентација: либерали су били оријентисани „пробритански“, конзервативци „Пронемачки“. Први су тежили да уклопе руску спољну политику у оквир британских интереса. Други су, без обзира на рат, тежили да после рата не дође до претераног слаблења и урушавања немачког утицаја у средњој Европи, јер су у руско-немачким односима видели вековне традиције конзервативног уређења у централној Европи. Руски министар спољних послова (1910-1916), С. Д. Сазонов, спадао је у редове пробританских политичара. ${ }^{23}$ Стајао је чврсто на становишту да је за остваривање руских планова на Балкану потребно добијати сагласност Енглеске. ${ }^{24}$ Тај став је у још већој мери био присутан у редовима ударне песнице руске думске опозиције - Партије кадета и њеног лидера, П. Н. Миљукова. Партија кадета је у својој спољнополитичкој оријентацији још више била усмерена на Енглеску. ${ }^{25}$

У току 1914. и 1915. (као и у случају са југоисточном Македонијом по питању српско-бугарског разграничења или са североисточним Банатом по питању српско-румунског) јужнословенско питање се фактички решавало у оквиру захтева других потенцијалних савезника Антанте у региону; радило се о уступцима на рачун послератних граница нове државе са центром у Београду, где је жртвовање будућих аспирација Бео-

23 У свом извештају од 4. априла 1917. капетан Де Малејси из француске војнообавештајне службе чак је са очигледним претеривањем назвао С. Д. Сазонова „енглеским агентом“. Олег Ф. Соловьев, „Революция глазами Второго бюро (донесения сотрудников французской разведки капитана де Малейси и генерала Нисселя)“, Свободная мысль 9/1997.

24 АЈ, Ф. 80, ф. 2, 466.

25 Alexey Timofeev, Milana Živanović, „Carnegie Report on the Causes and Conduct of the Balkan Wars 1912/13 in Serbia", Tokovi istorije 3/2016. 
града морало да побољша његову тренутну ситуацију. ${ }^{26}$ Ипак, без обзира на све рубне осцилације, за општесрпске интересе била је повољна спољна политика владајућих елита царске Русије. Либерализација руске унутрашње политике водила би, према мишљењу српских дипломатских представника, слабљењу руске подршке за српске спољнополитичке интересе. Две године пре револуције (у августу 1915) српски посланик Спалајковић је писао: „са евентуалном победом струје у корист парламентаризма дошли би на власт елементи као Миљуков, са свим његовим србофобским тежњама и утицајем на спољну политику“.27 Револуција 1917. је показала да је и Миљуков могао бити не најгора варијанта у руском државном врху по српске интересе.

Уз све ове финесе мора да се истакне да је питање Цариграда било кључно за руску спољну политику у Првом светском рату, и према њему је и питање уласка хрватске Далмације и Словеначког приморја у будућу јужнословенску државну заједницу имало секундарни значај у очима Петрограда. За разлику од западних граница будуће јужнословенске државе, питање црноморских мореуза имало је за руску царску дипломатију изузетан економски и идеолошки значај. Према речима министра Сазанова, почетком 1915. „руска званична политика, сва је управљена решењу питања о Дарданелима, уступа под пресијом Јадранско и Југословенско питање (...) у погледу Истрије и највећег дела Далмације“.28 Руска царска дипломатија се већ у јуну 1915. бавила разрађивањем статута за Цариград. Бавили су се чак и персоналним кадровским решењима за руску администрацију у још неослобођеном граду: руског посланика у Београду, Трубецког, планирали су за цивилног комесара града, а

\footnotetext{
26 AJ, Ф. 80, ф. 2, 392.

27 AJ, Ф. 80, ф. 2, 480.

28 AJ, Ф. 80, ф. 2, 473.
} 
директора Руског археолошког института, Ф. И. Успенског, за главног архивског надзорника. ${ }^{29}$

Ову еуфорију прекинуло је инсистирање руске војне команде на немогућности извођења десантне операције у мореузима $1915 .^{30}$ Тешко је рећи да ли се овде радило о неспремности, типичној за последње године постојања руске царске војске, обичној опрезности у планирању, ${ }^{31}$ или о неким дубљим разлозима, јер би власт цара који би ушао на челу руске војске у Цариград било немогуће ограничити. (Касније се испоставило да је официрска група на челу са генералом Алексејевим активно учествовала у припремама и извођењу револуције годину и по дана после несуђене експедиције).

Вероватно су утицале све ове чињенице. Битно је то да је у исто време, у току 1915., Енглеска покушала да да̂ све од себе да заузме Дарданеле у операцији Галипоље, чувеној по свом неуспеху, али и ратним напорима. ${ }^{32}$ Сигурно је да хектолитри крви које су пролили становници Британије и доминиона нису жртвовани због потребе да се Цариград преда Русији, већ због супротних разлога. Интересантно је да је одмах после британског пораза код Дарданела, руске победе на Турском фронту и пада Ерзерума генерал Алексејев пожурио да изнесе предлог о склапању мира са Турском, уз потпуно руско одустајање од било какве корекције граница и уз про-

29 АЈ, Ф. 80, ф. 2, 708; Народна библиотека Србије (НБС), Фонд Смирнов, Воспоминания о Великом князе Константине Константиновиче, 2.

30 Василий Б. Каширин, „Несостоявшаяся экспедиция русских вооруженных сил на Балканы осенью 1915 года“, Новая и новейчая история 6/2004.

31 Брюс У. Меннинг, Пуля и штыю. Армия Российской империи, 1861-1914, (Москва: Модест Колеров, 2016).

32 Harvey Broadbent, Gallipoli: The Fatal Shore, (Camberwell: Viking/ Penguin, 2005); Александр К. Коленковский, Дарданельская операция, (Москва-Ленинград: ГИЗ, 1930). 
глашење повратка Цариграда „илузијом која зачарава“. Према том предлогу, руска војска је требало да се усмери на обрачун са Немачком, да она повуче своје трупе од мореуза, што би обезбедило „Енглеској да слободно дише јер би престала опасност од напада на Египат“. Требало би, у случају победничког завршетка рата, да се Русија задовољи повратком на своје државне границе и поразом Немачке... ${ }^{33}$ Ваљало би подсетити да је руска влада већ од почетка рата говорила о обнављању пољске државе (састављене од руског, аустријског и немачког дела). Дакле, на подручју руско-немачке границе морало је доћи само до смањивања територије царевине. Према идеји генерала Алексејева, Русија - која је изгубила војника више него било која држава Антанте - требало је да се задовољи смањивањем државне територије као последицом вишегодишњих ратних напора. Последњи пут када је Русија попустила на дипломатском плану, након двогодишњих општенародних напора у победничком рату (1877-1878), разочарање је водило слабљењу ауторитета царске власти и јачању револуционарног покрета. Очигледно је да је предлог официрске врхушке, крупне буржоазије и политичара из Думе могао донети исти резултат.

Интерно кривицу за фебруар 1917., али и за оно што је претходило догађајима, осећала је и војна и политичка врхушка која је извела државни удар. Илустративна је породична историја коју је Олег Михајлович Родзјанко (1923-), унук М. В. Родзјанка (1859-1924), изнео у документарном филму 2013. године. Наводно је његовом деди, једној од кључних фигура државног удара 1917.,

33 Сборник секретных документов из архива бывшего Министерства иностранных дел, № 1 (декабрь) приређивач Н.Маркин, (Петроград: Народный комиссариат по иностранным делам, 1917), 12-14. 
„Врангел, командант Беле армије, већ у емиграцији рекао да су крива била војна лица [генерал Алексејев], која су наговорила цара да абдицира, а ми њих не смемо прогласити за кривце, и зато смо морали да изаберемо [за главног кривца] Вас“. ${ }^{34}$ Наравно, овај исказ не може служити као стварни доказ раскајања истакнутих револуционера у униформи и поготову самог генерала Алексејева (који као оснивач белогардејског покрета није смео у очима својих сабораца носити ни мрвицу кривице за Фебруарску револуцију), али итекако сведочи да је осећај кривице мучио не само М. В. Родзјанка већ и његову породицу. У овом контексту веома је илустративно и „писмо Миљукова из августа 1917”. ${ }^{35}$ У њему се имплицира одговорност думских политичара (кадета и прогресиста) за намерну саботажу са циљем бробе за власт: „Знате да је чврста одлука да искористимо рат за организацију државног удара била прихваћена код нас убрзо након избијања рата, ви знате такође

34 Фильм Русский корпус. Свидетельства, реж. М. Л. Ордовский (Санкт-Петебург: Ростик фильм, 2014), 1 серия 18:36-19:08.

35 Сам политичар негирао је своје ауторство (Павел Н. Милюков, „Старый подлог“, Последние новости, бр. 454, (Париж), 8 октября 1921, 2-3). На веродостојности писма инсистирали су руски емигранти: Евгений А. Ефимовский, „Лицо и изнанка“, Возрождение 56/1956, (Париж), 135-145); Евгений Ефимовский, „Политический сфинкс“, Возрождение 102/1960, (Париж), 106-116; Александр А. Лодыженский, Воспоминания, (Париж: б. и, 1984). Исто мишљење делили су и многи совјетски историчари: Валентин С. Дякин, Русская буржуазия и иаризм в годы первой мировой войны (1914-1917), (Ленинград: Наука, 1967), 288; Владимир А. Кувшинов, Разоблачение партией большевиков идеологии и тактики кадетов (февраль-октябрь 1917 г.), (Москва: МГУ, 1982), 37; Василий Д. Поликарпов, Военная контрреволючия в России. 1905-1917 22., (Москва: Наука, 1990), 249-250; Александр С. Сенин, Александр Иванович Гучков, (Москва: Скрипторий, 1996), 153; Анатолий Ф. Смирнов, Государственная Дума Российской Империи, 1906-1917: Историко-правовой очерк, (Москва: Книга и бизнес, 1998), 582. 
и да је наша војска морала прећи у офанзиву, чији би резултати у темељу прекинули незадовољство, изазвали би у земљи експлозију патриотизма и одушевљења. Схватате сада зашто сам оклевао у последњем тренутку да дам сагласност на извођење удара, такође схватате и то какво би требало да буде моје унутрашње стање у овом тренутку“" ${ }^{36}$ Напредовање руске војске према Цариграду сметало је не само опозиционим думским политичарима већ и савезницима, односно Енглеској.

Много пре Првог светског рата питање припадности Цариграда постало је кључно за сукоб енглеских и руских интереса на Балкану. Нећемо ићи у далеку прошлост јер је овај конфликт имао вишегодишњу утемељеност у сукобу две империјалне снаге. Ипак, постојање овог сукоба већ од XVIII века и мањи изгледи за његово безболно решење (уз помоћ дипломата, а не војника) у XX веку били су очигледни чак и неколико деценија после Првог светског рата, када су амерички обавештајци сматрали британско ометање руског ослобођења Цариграда традиционалном вишевековним ступом енглеске политике на Балкану. ${ }^{37}$

Beћ 1908. енглеска влада је заузела дефинитиван и оштар став против било каквих руских покушаја да дођу до ексклузивног утицаја на црноморске мореузе. ${ }^{38}$

36 Лодыженский, н. д., 91-92.

37 Види, на пример, елаборате америчке обавештајне службе настале 1945, када је по завршетку Другог светског рата поново дошло до потребе решавања питања црноморских мореуза. The Soviet Union and the problem of the Turkish straits, T-516, January 24, 1945 (CIA-RDP08C01297R000500030010-5); The Great Britain and the problem of the Turkish straits, T-517, January 24, 1945 (CIARDP08C01297R000500030009-7).

38 Сборник секретных документов из архива бывщего Министерства иностранных дел, № 1 (декабрь), приређивач Н.Маркин, (Петроград: Народный комиссариат по иностранным делам, 
На посебној седници посвећеној питању црноморских мореуза, у присуству министра спољних послова, министра војног и министра морнарице, 8. (21) фебруара 1914, начелник Црноморског оперативног сектора Поморског генералног штаба царске Русије, А. В. Њомиц (Нёмитц), је рекао: „на путу ка мореузима Русија има озбиљне непријатеље не само од стране Немачке и Аустрије. Ма колико да су успешне наше акције на западном фронту, оне нам неће дати мореузе и Цариград. Њих могу заузети туђе морнарице и војске, док траје борба на нашој западној граници (...) једино што можемо је да заузмемо Цариград и мореузе уз помоћ наше војске, да наше освајање ових тачака у тренутку мировних преговора буде свршен чин. Само у том случају Европа ће се сложити са решавањем питања мореуза под тим условима, под којима нам је то неопходно“. ${ }^{39}$

Одмах по избијању рата (чак пре ступања у рат Турске и Бугарске) руске дипломате су почеле да размишљају о будућим резултатима ратних напора Русије у светском рату. Корекције границе са Немачком и Аустријом (аустријска Галиција и немачки делови Пољске) руски посланик у Србији, Трубецки, у писму посланику у Цариграду, М. Н. Гирсу, назвао је „поравнањем историјских рачуна, а не посебно корисним резултатом“. Поред тога, мореузи су, у случају турског учешћа у рату, морали да постану кључни ратни циљ којем би Русија тежила, као компензација за ратне напоре због ванредног стратешког значаја. С друге стране, испољавала се одређена сумња у савезничку спремност да признају руске интересе по питању Цариграда. ${ }^{40}$ По

1918), 26-28.

39 “Из журнала Особого совещания 8 февраля 1914 г.“, Вестник Народного комиссариата по иностранным делам 1/1919, 32-41.

40 Константинополь и проливы. По секретным документам 6. 
ступању Турске у рат ово планирање добило је посебан значај. Већ у фебруару 1915. у разговору са Трубецким српски премијер Пашић са забринутошћу је констатовао да освајање Цариграда од стране западних савезника без учешћа Русије (будућа Дарданелска операција) „може да да̂ решавању овог најбитијег за Русију задатка правац који неће да одговара правима и очекивањима Русије“.41 То су схватали и у Русији. Тадашњи потпуковник Генералног штаба царске руске војске, А. К. Коленковски, писао је 1930. у својим успоменама, већ као генерал Црвене армије, да је за Дарданелску операцију Енглеска тражила и искористила повољну прилику: не тада када су Турци били најслабији или кад су Енглези могли да рачунају на помоћ руског савезника, већ када су руске снаге почетом 1915. биле заузете и на Кавкаском и на Варшавском фронту, а Русија је могла само да одобри енглеску операцију у Дарданелима. ${ }^{42}$

После рата А. В. Њомиц (Нёмитц), већ као совјетски адмирал, који је за време грађанског рата руководио револуционарном морнарицом Руске совјетске републике, у својим мемоарима износио је исте погледе на минули рат: „За прву размену мишљења између Генералног штаба војске и флота по овом темељном питању била је сазвана горе поменута посебна седница, под вођством министра иностраних дела С. Д. Сазонова. Уз то директива за његов рад морала је да постане већ одобрена од цара (...) основна идеја новог поморског плана рата. Седница је отворена чињеницом, коју су њени организатори уочили и пре тога: војнички план рата није потпуно повезан са поморским. План Генералног шта-

Министерства Иностранных Дел, кн. 1, ред. Е. А. Адамов, (Москва: Издание Литиздата НКИД, 1926), 156.

41 Исто, 383.

42 Коленковский, н. д., 17-18. 
ба војске је предлагао офанзиву на Западном фронту на Аустрију и Немачку (уместо активне одбране). Само после пораза Немачке и Аустрије могао је, према том плану, започети Цариградску операцију. Овај план је био користан за Француску и Енглеску, али је занемаривао државне интересе Русије, није штедео њене народе, који су морали да жртвују у тешким офанзивима милионе живота, и обећавао је погибију царском режиму. Размена мишљења није променила ставове Генералног штаба војске, али није ни обесхрабрила ни [нас] присталице новог, другачијег плана рата. Очекивала се и даља борба мишљења у којој је на нашој страни била и лична воља самог цара. Судбина је ипак решила против нас“. ${ }^{43}$ Енглеска и Француска су биле против јавног и званичног признања права Русији на Цариград и мореузе све до краја 1916. ${ }^{44}$ У поверљивим преговорима 12. марта 1915. Енглеска је признала своју сагласност на прелазак Цариграда под власт Русије, а 10. априла 1915. с тим се сложила и Француска. ${ }^{45}$ На Цариград је као на основни циљ Русије у рату гледао и руски цар Николај II који је у Високом манифесту од 12. децембра 1916. изјавио: „Решавање војних задатака које је Русији поставио рат, запоседање Цариграда и мореуза, као и стварање слободне Пољске од свих њених раздвојених делова, још увек није постигнуто. Склопити данас мир би значило да се не икористе плодови напора Руске војске и морнарице“.

Међутим, идеја да ће Русија морати да добије компензацију на Балкану, као надокнаду за ратне напоре и два

43 Гражданская война в России: Черноморский флот, приређивач В. Доценко, (Москва: АСТ, 2002), 310.

44 Щеголев, н. д., 181-183.

45 Harry Howard, The Partition of Turkey: A Diplomatic History, 19131923, (Norman: University of Oklahoma, 1931), Ch. 4. 
милиона изгубљених живота, није могла да се допадне Енглеској. И док је у Лондону радила краљевска комисија за истраживање разлога катастрофе енглеске војске код Дарданела, ${ }^{46}$ у Русији је била активирана вишесмерна делатност уперена на смену политичког режима. За време јануарске конференције 1917. у Петрограду савезници су „разговарали са лидерима руске буржоаске опозиције и били су у току са тим радом на организацији државног удара коју су водиле енглеска и француска амбасада и Прогресивни блок Думе. Њих није плашило повећање незадовољства у земљи, долазак на власт буржоаских лидера изгледао је пожељно. Руска војска у њиховим очима није губила свој значај као битан фактор у војном рушењу Немачке“.47 Савезничка конференција 1917. потврдила је прелиминарне обавезе и планове савезника, мада се углавном бавила питањем координације и организације савезничких ратних напора. ${ }^{48}$ Српска влада је сазнала 9. (22.) фебруара 1917. да је конференција завршила свој рад у Петрограду и да су делегати отпутовали за Порт-Романов (Мурманск). Једино је Специјални одбор за устројство будуће Пољске продужио рад још два дана. ${ }^{49}$

Након неколико дана, 15. (28) фебруара 1917, званичне Српске новине на Крфу ставиле су на прву стра-

46 Комисија је започела рад у августу 1916, а званични закључак рада у облику извештаја саставила је почетком фебруара 1917. Office-Holders in Modern Britain, Volume 10: Officials of Royal Commissions of Inquiry 1870-1939, by J. Harrison, (London: Institute of Historical Research, 1995), 85-88.

47 Сидоров, н. д., 434.

48 Василий И. Гурко, Война и революиия в России. Мемуары командующего Западным фронтом. 1914-1917, (Москва: Центрполиграф, 2007), 288-305.

49 Велики рат Србије за ослобођене и уједиюеюе Срба, Хрвата и Словенаца: 1914-1918 2., Књ. 21: 1916 и 1917. година, (Београд: Главни ђенералштаб, 1931), 420-421, 425-426. 
ницу обиман чланак у коме је констатовано да је „Питање Цариграда једна хиљадугодишња преокупација целокупне руске спољне политике и целокупног руског интелектуалног живота (...) У том истом смислу, Русија је водила ратове са Турском и у XIX веку, и том је приликом, да би словенство приближила Цариграду, ослободила и Бугарску која се, сада, заједно с том истом Турском, бори против Русије. Сви старији и новији словенофили створили су били од тог питања читаву једну идеологију и читав један социјално-политички систем. Рекама је проливена руска крв за тај идеал. Песници и филозофи, научници и државници, војници и политичари, писали су о томе сваки на свој начин. Постоји о томе у Русији читава литература, и она постоји од вајкада (...) Данас, када је непријатељ за свој грандомански сан Берлин-Багдад, довео ствари до овога стања, питање се само наметнуло и истакло на дневни ред. Савезници, на својим конференцијама, уређујући будућу карту Европе, изнели су и то питање на светлост, и дали му решење у смислу хиљадугодишњих снова и у смислу животних потреба Русије”. Одмах након овог чланка стајао је интервју са председником Министарског савета и министром иностраних дела Србије, Николом Пашићем, који је кратко резимирао своје виђење будућности Србије: „За нас, Србе, овде је у питању ослобођење наше земље, препуштене освајачу, чија су почињена насиља позната свима. Велика Србија је жива у срцима свих Срба, и ми ћемо је са нашим Савезницима и остварити". ${ }^{11}$ Уздање у руску помоћ у свим српским подухватима било је изузетнио раширено у српској влади. ${ }^{52}$

50 „Русија и питање Цариграда“, Српске новине, 28. фебруар 1917.

51 „Изјаве Г. Пашића“, Српске новине, 28. фебруар 1917.

52 Велики рат Србије за ослобођење и уједиюење, 649. 
У телеграму од 25. фебруара (10. марта) српски посланик у Петрограду, Спалајковић, саопштио је Пашићу о аудијенцији кнегиње Јелене Петровне (1884-1962), кћери краља Петра I Карађорђевића и супруге кнеза Иоана Константиновича Романова (1886-1918), код цара Николаја II. Констатовао је потпуну подршку коју је Србија уживала у Русији у последњим данима уочи револуције: „Цар је добро расположен и најбоље се изразио о нашем корпусу и генералу Живковићу који ужива опште уважење и симпатије. Српски престиж код цара још се више уздигао у поређењу са Румунима којима је цар потпуно разочаран (...) Кнегиња Јелена постаје све више симбол крвне и политичке везе између нашег народа и Русије. Тактична и ретка интелигенција врши улогу на најкориснији начин по нашу отаџбину”.53

Утицај промена политичког стања у Русији после Фебруарске револуције за српску ствар истакао је веома јасно српски генерални конзул у Одеси, Марко Цемовић, 6. (19) марта 1917. у свом извештају Пашићу. Констатовао је: „до јуче, до преврата, српска национална идеја имала је најискренијег заштитника у лицу цара Николе. Љубав, истинита љубав бившег цара према Србији и српском народу припомогла је, да виша бирократија акцептира идеју Југославије. С падом цара и с њиме старога бирократског апарата, разрушено је у знатној мери оно, што смо ми до сада радили и урадили у политичким круговима старога режима. Однос партија у Думи према нашем питању био је разнолик, али ни код једне групе није био довољно јасан и одређен“". 54

Силазак цара Николаја II са престола донео је политичкој елити Србије узнемирење и забринутост. У

53 АС, МИД, ПО, 1917, ф. IХ, д. II, 84.

54 АС, МИД, ПО, 1917, ф. IХ, д. III, 173-181. 
српско-руским односима дошло је, према М. Јовановићу, до завршетка „периода руског покровитељства и српске борбе за независност“ који су трајали два века. Србија, поробљена и разапета, спремала се за велики тријумф 1918, када су се све српске територије нашле у оквиру једне државе, толико значајне да је „српска политичка елита, предвођена династијом Карађорђевића, добровољно утопила независност и државност Србије у новоформирану државу јужних Словена“. стране, услед Фебруарске револуције, коју су методом државног удара извели делови војне и цивилне елите, уз подршку заинтересованих страних сила, Русија се нашла у највећој кризи у својој новој историји, која је започела процес територијалног распада не само етничких провинција већ и историјског језгра руске државе, када је за годину дана од аутономије Малорусије дошло до стања „када се одвајање јужне од северне Русије све више опредељивало као неизбежно“. ${ }^{56}$ Привремена влада и посебнњо њен пејаница А.Ф.Керенски су дали томе немерљиви допринос.

У околностима рађања регионалних сепаратизама ново окупљање руских земаља није могло да иде само под лозинком „за једину и недељиву Русију“ коју су са накнадном памеђу истицали белогардејци већ је био потребан неки општи идеолошки пројекат, који након неколико месеци покушаја није успела да изнедри ниједна већа и позната странка у току 1917. Осим једне - бољшевичке, чији су лидери осетили потребу значајног дела становништва Русије за јасним и општеприхватљивим лозинкама - мира и социјалне правде. Успон нове бољшевичке Русије био је изненађење за „савезнике“ и за широке слојеве руске интелигенције која је жељно оче-

55 М. Јовановић, Срби и Руси, 12-21. век: историја односа, (Београд: Народна библиотека Србије, 2012), 69, 156 .

56 Велики рат Србије за ослобођење и уједиюеюе, Књ. 24, 659-660. 
кивала „час устав, час кувану пастругу са реном“"57 пре фебруара 1917, а после са мржњом гледала гомиле на улицама и вапила „Митраљезе! Митраљезе!“58

Поглед српске елите на револуционарне догађаје у Русији имао је неколико нивоа. Први и најбитнији сигурно је произлазио из актуелне ситуације - односа према Русији као непресушном извору различитих материјалних ресурса, људске снаге и дипломатске подршке преко потребних једној држави скоро без слободне територије, скоро без војске, без општепризнатих граница и без јасног концепта будућег уређења. Овај однос се уклапао у општи однос других „савезника“ (Енглеске, Француске, Румуније итд.) који се сводио на једноставну обавезу Русије да ратује „због савезничког дуга“, уз што мање претензије на послератну награду и уз безбројне жртве у току рата. У оквиру ове концепције српска дипломатија заједно са другим савезничким дипломатијама, поздравила је Фебруарску револуцију, а после, све до смрти несрећног генерала Духоњина, у новембру 1917., очекивала је од Русије стално напрезање војске већ неспособне за ратне напоре.

У извештајима српске војске, и нешто мање у извештајима дипломатије, види се и један дубљи, традиционалнији однос према Русији који је потицао из вишедеценијског и чак вишевековног искуства руско-српских односа. ${ }^{59}$ Базирао се на сагледавању више-

57 М. Е. Салтыков (Н. Щедрин), Культурные люди, Собрание сочинений в двадиати томах, Т.12, (Москва, Художественная литература, 1971)

58 В. В. Шульгин, Дни. 1920, (Москва, Современник, 1989).

59 С. Долгова, Е. Иванова, А. Турилов, Т. Суботин-Голубовић (приредили), Москва-Србија, Београд-Русија. Документа и материјали: Том 1: Друштвене и политичке везе XVI-XVIII век, (Београд: Архив Србије, Москва: Главное архивное управление города Москвы, 2009). 
кратних осцилација Русије која је имала више периода падова и успона у својој прошлости.

Добар пример ове вишеслојности су писма и препоруке Н. Пашића српским дипломатама после Фебруарске и Октобарске револуције. Уз рационални страх од бугарофилских испада првог министра иностраних дела у Привременој влади, П. Н. Миљукова, Н. Пашић препоручивао је да треба подесити „своје држање, свој говор и своја општења са руским политичарима“ новонасталој ситуацији, у циљу да се продре у оно «што се иза кулиса спрема» ${ }^{60}$. С друге стране, у одговору на циркуларно писмо П. Н. Миљукова о формирању Привремене владе, Н. Пашић је достојанствено и опрезно оценио абдикацију Николаја II као „узвишени пример патриотизма који је Цар својим одрицањем показао целом свету, а у првом реду Славенима, да би се у интересу отаџбине постигла слога и прибрала сва снага руских грађана“, а након тога, уз ништа мању опрезност и донекле двосмисленост, пожелео је Русији у име целокупног српског народа „да организована на демократским основима, надмаши својом славом, својом моћи и својим цивилизаторским радом сва своја стара славна времена“. ${ }^{61}$ Након Октобарске револуције и бољшевичких покушаја да се склопи мир Н. Пашић је сигурно схватио да се већина пожељног неће у скорој будућности остварити, ${ }^{62}$ али ипак није губио наду у Русију, макар и „бескорисну“ по Србију у датом тренутку, када је рекао: „Пролазимо врло тешке часове, али не смемо очајавати; када мину ови месеци, који су најтежи од свих до сада, наша општа ситуација кренуће без сва-

60 АС, МИД, ПО, 1917, ф IX, д. II, 128.

61 АС, МИД, ПО, 1917, ф ІХ, д. II, 90-92.

62 „Изјаве г. Николе Пашића. О максималистичким предлозима за мир“, Српске новине, 30. децембра 1917, 2. 
ке сумње, на боље. За сада главно је истрајати, а ја се поуздано надам, да ћемо ми истрајати. Анархија која влада у Русији дозволила је непријатељу да постигне такве успехе, каквима се није надао. Не може се говорити о руској револуцији, већ о руској анархији у правом смислу речи. Оно што се догађа у оној огромној држави последица је пространости територије и замршеног комплекса њених проблема. Али ја се сигурно надам да ће Русија наћи свој пут којим ће доћи до свога преуређења“.63 Индикативно је да је ово метафизичко и широко сагледавање ситуације у Русији кроз перспективу вишевековних руско-српских односа давало боље резултате него утилитарни приступ у који су посебно често западале дипломате и због тога долазиле до суштинских грешака у прогнозирању. Пашићева визија константи руско-српских односа помогла му је на крају крајева да донесе веома битну одлуку и да забрани мешање српских трупа у догађаје револуције и грађанског рата, макар и на страни која је њему изгледала привлачно. Ипак, ова линија није била доминантна, а поједностављивање ситуације се у највећој мери концентрисало у сажетом излагању извештаја српских представника у Русији за потребе наследника српског престола. ${ }^{64}$

Наравно, српско сагледавање Русије у револуционарној 1917. много је шире од погледа српске елите (оставили смо по страни погледе српских интелектуа-

63 „Изјаве г. Пашића. Председник Српске Владе о ситуацији у Русији“, „о положају на Балкану и о односима између Србије и Италије, “ Српске новине, 30. децембра 1917, 1-2.

64 Сачувано у АЈ, ф. Канцеларија Њ. В. Краља, пов. бр. 117, Ф-2. Објављено у: Дипломатска преписка Српске владе 1917. год.: збирка докумената, приредили Миодраг Зечевић и Миладин Милошевић, (Београд: Народно дело, Архив Југославије, 1991, $337-364$. 
лаца, који су се нашли у Русији 1917, ${ }^{65}$ погледе српских револуционара, ${ }^{66}$ као и комплекс проблема српског корпуса). ${ }^{67}$ Међутим, и у погледима „незваничних Срба“, као и у погледима званичне Србије, тешко можемо пронаћи дубље трагове расплета руске трагедије 1917-1918, када су људи који су организовали Фебруарску револуцију касније учествовали у организцији Грађанског рата. Ове људе је истакнути научник, проф. Н. В. Крајински, у својим објављеним у Београду емингрантским мемуарима назвао „злим дусима Фебруарске револуције и рушитељима Руске империје“.68 Српским дипломатским и војним представницима било је тешко да схвате да су се белогардејски лидери „борили за успостављање Русије Љвова, Миљукова, Керенског и само су жељели да заузму њихово место“, 69 што сигурно није могло да им донесе подршку ширих слојева руског народа. Тек у глобалном конкексту сагледавања руске историје неко у далекој 1917. могао је да предвиди расположење ширих слојева руских интелектуалаца, чије је гледиште

65 Љубинка Трговчевић, Научници Србије и ствараюе југословенске државе: 1914-1920, (Београд: Народна књига, 1986); Милош Московљевић, У Великој руској револуичји: дневничке белешке, приред. М.Исић, (Београд: Институт за новију историју Србије, 2007).

66 Никола Б. Поповић, Срби у грађанском рату у Русији 19181921, Београд: Институт за савремену историју, 2005.

67 Армия без государства. От сербского к югославянскому добровольческому корпусу в России во время Первой мировой войны. Сборник документов, приредили Алексей Тимофеев, Яарослав Вишняков, Горан Милорадович, (Москва: Росийский институт стратегических исследований, Российское военно-историческое общество, Институт Андрича-Отдел истории, 2014).

68 Н. В. Краинский, Фильм русской революичи в психологической обработке, (Белград, 1940), 563.

69 Константин Глобачев, Правда о русской революици: Воспоминания бывщего начальника Петроградского охранного отделения, (Москва: РОССПЭН, 2009), 265. 
резимирао проф Н. В. Крајински: „Ми (емигранти) смо противници бољшевика. Али када видимо да Молотов сада враћа украдене од Русије крајеве, ми (монархисти) смо спремни да му аплаудирамо, видимо у његовим акцијама одмазду за злочине против Русије“.70

Уосталом, одређена кратковидост у сагледавању трендова развоја Русије била је типична не само за српске званичнике који су истицали наду да „револуција неће да промени ништа у Русији“, већ само да одстрани реакционарне делове администрације и убрза рад механизма. Како се испоставило без овог „реакционарног тела“ руски војник се претворио у анархисту и дезертера, чију слику у облику револуционарно свесног Шарикова који може да се упише у ратну евиденцију, али неће да иде на фронт, макар и против „империјалистичких звери“, алегоријски је приказао М. А. Булгаков ${ }^{71}$.

Октобарска револуција пружила је делу руског народа неку идеју, која га је поново вратила у традиционални идеократски модел, уз повлађивање хилијастичким, егалитаристичким и месијанским концептима који су се вековима баштинили у руском сељаштву. Октобарска револуција је, с друге стране, на неко време раздвојила Русе и Србе, јер се њихови савезници, интереси и перспективе више нису поклапали. У овом контексту праву револуционарну Русију могли су да схвате и генерал А. А. Брусилов ${ }^{72}$ и адмирал А. В. Немитц, ${ }^{73}$ али нису могли да схвате доскорашњи присни савез-

70 Н. В. Краинский, Фильм русской револючии в психологической обработке, 586.

71 М. А. Булгаков, Собачве сердие, Собрание сочинений в 10 томах. Том 03, (Москва: Голос, 1995), 101.

72 А. А. Брусилов, Воспоминания, 269-271.

73 Гражданская война в России: Черноморский флот, приређивач В. Доценко, (Москва: АСТ, 2002), 322. 
ници - Срби, као што се то види извештаја званичних представника Србије. Нова совјетска Русија морала је да се бори против доскорашњих «савезника», који су комадали њену територију, подржавајући стварање марионетских режима и држава од Кишињева и Кијева до Иркутска и Владивостока. Бољшевици су се субјективно борили за своју идеологију, али објективно (са вековне дистанце) за јединство историјске Русије. У овој борби совјетска Русија је стасавала и јачала, толико да је након две деценије успела да заврши рат са немачким хегемонизмом у Европи, који царска Русија није издржала до краја. У новом рату на путу немачке експанзије поново су се нашли Срби и Руси. У том другом рату за Србију се питање рата повезало са питањем грађанског рата, а „савезници“ су инсистирали на наставку ратних напора без обзира на „идеолошке промене“ и објективну бескорисност даљег крварења. У новим околностима остарели М. Спалајковић, некадашњи навијач за наставак ратних напора „због савезничког дуга и обавезе борбе за слободу неослобођених нација“, без обзира на цену, подржавао је излазак српског народа из рата. «Ко сад међу Србима може још да сумња у искрену љубав и пријатељство Енглеске према српском народу?», вапио је и бацао клетве на „главне лиферанте српске крви за Енглеску“ и на „Већ сад црвеног од толике туђе крви Британског камелеона, који црвенеће после свога срамног слома, још и више од - вечнога стида“ ${ }^{74}$ На тај начин опет је доказао своју неспособност да уочи шири контекст догађаја и да прозре правац историјског расплета. Значајан део српских званичника, очевидаца догађаја, сачувао је своје разочарање у руску револуцију, од 1917. до самог краја свог живота...

74 АС, Ф. М. Спалајковић, д. 66. 
Упркос свему, револуционарна 1917. није успела да сломи вековне традиције руско-српских односа и само је укрстила неке чудне токове и дешавања, створивши нове линије у односима. Србија је постала уточиште хиљадама руских емиграната после грађанског рата, али је спасла и значајан број познатих учесника бурне 1917. На свечаној парцели Новог гробља у Београду поред гроба војводе Ж. Мишића вечни мир су нашле кости генерала М. В. Алексејева, који је одиграо толико контроверзну улогу у нестанку Руске царевине. У међуратном периоду у Србији су живели активни организатори абдикације Николаја II, политичари В. С. Шуљгин и М. В. Родзјанко, с тим да је последњи чак и сахрањен на Новом гробљу у Београду. Најзад, у српској официрској униформи и са српским пасошем на име капетана Милутина Марковића, који је издао српски заступник у Москви, Р. Јовановић, у возу са српским официрима бежао је из Москве у Мурманск, а одатле у Лондон, несуђени вођа демократске Русије - Александар Ф. Керенски. ${ }^{75}$ У Првом светском рату Руси и Срби као и многи други европски народи нису успели да потпуно заокруже планирано и очекивано пред светски рат. Уосталом и цела међуратна Европа није стекла дефинитивни и чврсти мир 1918., када је деформисана версајским променама Европа судбоносно кренула према новом светском рату. Русија се повукла са Балкана 1918. да се

75 Александр Ф. Керенский, Россия на историческом повороте: Мемуары, (Москва: Республика, 1993), 341; Антон И. Тучков, "Министр-председатель в сербском мундире. А. Ф. Керенский" : Петроград-Мурманск-Лондон, Наука и бизнес на Мурмане: Мурман - Сербия, № 3(48), 2005, 11-18. О раду српске мисије у бољшевичкој Русији 1918-1919. види: Радослав Ст. Јовановић, Зашто сам и како био и остао у Русији од 1913. до 1923. године: кратки меморандум министру спољьих послова Кратевине Срба, Хрвата и Словенаца, (Београд: Југославија, 1925). 
врати веома брзо чак у две форме - у облику беле руске «Русије у егзилу», и у облику црвених идеја Совјетске Русије. И једна и друга и те како су утицали на даљи развој нове државе са центром у Београду након Првог светског рата ${ }^{76}$.

76 Од најновијих радова на ову тему види: А.Тимофејев, М.Живановић, Уибеник за Тита: Коминтерна и припреме партизанског рата у Европи, Београд, 2018; Р.Пилиповић, Српска православна ирква и руска емиграција 1920-1940, Бања Лука, 2018. 